論 文

\title{
レーザースリット光と画像を用いた破砕堆積物 認識のためのビジョンシステム
}

\author{
高 橋弘*, 山 崎 勝 幸** \\ A Vision System for Recognition of Piled Fragment
Rocks by Using Laser Slit Light and Images \\ by \\ Hiroshi $\mathrm{TAKAHASHI}^{\dagger}$ and Katsuyuki $\mathrm{YaMAZAKI}^{\dagger}$
}

\begin{abstract}
Recently, robotics has been receiving considerable attention in many fields, especially in mining, civil engineering and construction field because the working environment in these fields is severe for workers to work. However, it is very difficult to apply the robots or autonomous machines to these fields because the working environment changes according to the advance of the work. Therefore, robots should have an ability to understand the change of the working environment and to work autonomously.

The purpose of this study is to investigate the vision system for understanding the piled fragment rocks by using a laser slit and an image. In this study, the method to judge the existence of the piled rock was proposed by using the laser slit and image. Furthermore, the pattern of images was recognized by use of the template which was obtained in the preliminary experiment. Through this experiment, it was confirmed that this vision system worked well.
\end{abstract}

Key Words : Laser Slit, Vision System, Autonomous Machines, Matching, Image Processing

\footnotetext{
平成 8 年 9 月 2 日受付

* 東北大学大学院工学研究科地球工学専攻 厂 980-77 仙台市青葉区荒巻字青葉

** 東北大学大学院工学研究科資源工学専攻

ү980-77 仙台市青葉区荒巻字青葉

$\dagger$ Department of Geoscience and Technology, Tohoku Univ. Aramaki, Aoba-ku, Sendai 980-77

$\dagger \dagger$ Graduate School of Tohoku Univ.

Aramaki, Aoba-ku, Sendai 980-77
}

\section{1. 諸言}

近年, 資源開発および土木建設などの分野において, 過酷な作業現場からの作業員の解放抢よび安全確保の 面から，作業ロボットの導入が試みられている。これ らの現場に導入されるロボットは, 製造業などの分野 で使われているロボットとは異なり, 環境認識, 作業 動作，移動動作などを実行する機能を具備した自律型 ロボットであることが望ましい。しかし，このような 
分野における作業対象は自然界であり，かつ作業環境 が作業の進展にともない変化するため, ロボット化が 非常に困難な状況にある ${ }^{1)}$ 。

さて, 自律作業ロボットの実現には, ロボットが自 分の周囲の環境を認識しながら, 作業および移動動作 を行う機能を有することが必要不可欠である。環境認 識の手段としては, 種々の方法が提案されているが, 画像は比較的広範囲の情報を短時間に取得でき, かつ

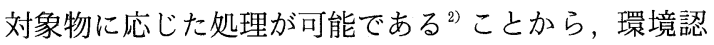
識には非常に有効であると考えられる。

ところで, 対象物の認識方法の 1 つにパ夕ーン認識 がある ${ }^{3)}$ 。これは, 対象物の特徵を予めテンプレート （標準パターン）としてコンピュータ内に蓄えておき, 実際に撮影された画像とテンプレートをマッチングさ せ，どのパターンに属するかを探し出すあのであり， 既に様々な生産ラインなどで用いられている優れた方 法である。しかしながら, 岩盤・岩石などの自然界を 対象とした場合, 作業の進行にともない対象物の形状 が常に变化するなど, 対象物の形状は一定ではなく不 定形であることから，テンプレートの作成が困難であ り, 自然界の物体を対象にしたパターン認識に関する 研究は見受けられなかった。

本研究では, パターン認識法の利点に着目し, 地下 資源開発現場などの地下環境における開発機械による 破砕堆積物（ずり山）すくい取り作業の自動化を目指 した基礎研究として, 破砕堆積物の堆積状態を認識す るためのビジョンシステムを提案する。ここでは, レー ザースリット光と画像を用いて対象物までの距離計測 を行い，この結果を 1 つのパターンと見なし，テンプ レートとのマッチングを行うことにより破砕堆積物の 堆積状態を認識する。つまり, 自然界のような複雑な 環境に対してテンプレートを用意し, パターン認識を 可能にした点に本研究の特徵がある。

\section{2. 本システムの原理}

\section{1 概要}

機械が自律的に作業を行うためには，まず作業対象 物の存在の有無を判断しなければならない。発破で起 砕された粒子群の自律すくい取り作業を考える場合, 作業対象物はずり山となる。すなわち，機械はずり山 があるかないかをまず判断しなければならない。本研 究では, ライン状のレーザー光を照射し, これを CC
D カメラで撮影した画像を用いてレーザー光が照射 されている位置までの距離計測を行い，その結果を基 に対象物の有無を判断する手法を提案する。ずり山の すくい取り作業では，この作業環境を構成する要素は, （1）壁面 (切羽)，(2）ずり山および（3）地面の 3 種 類であり, 撮影された画像は次の 7 パターンのいずれ かである。

$\begin{array}{ll}\text { (1)壁面一ずり山一地面 } & \text { (5)壁面一地面 } \\ \text { (2)壁面一ずり山 } & \text { (6)壁面 } \\ \text { (3)ずり山一地面 } & \text { (7)地面 }\end{array}$

(4)ずり山

このうち対象物であるずり山が存在するのは(1) (4) のパターンであり, (5)〜 (7)では存在しない。従って, 初めに, 撮影された画像を用いた距離計測結果により 対象物の有無を判断し，“有”之判断された場合は， (1)〜(4)のどのパターンに相当するかを認識することに する。また “無”と判断された場合に対しても(5)〜 (7) のどのパターンに相当するかを認識する。

\section{2 有無判断およびパターン認識のアルゴリズム}

画像中に含まれる情報は一般に 2 次元であるが，力 メラとレーザー光照射装置との位置関係を拘束条件と して用いれぱ, 2 次元の画像から 3 次元情報を抽出す ることが可能である。絶対座標系 $\Sigma(\mathrm{X}, \mathrm{Y}, \mathrm{Z})$ ，力 メラ座標系 $\Sigma_{\mathrm{c}}\left(\mathrm{X}_{\mathrm{c}}, \mathrm{Y}_{\mathrm{c}}, \mathrm{Z}_{\mathrm{c}}\right)$ および画像座標系 $\Sigma_{\mathrm{I}}$ $\left(\mathrm{X}_{\mathrm{i}}, \mathrm{Y}_{\mathrm{i}}\right)$ をFig. 1 に示すように定義する。ずり山に レーザー光を照射した場合, レーザー光が当たってい るライン上の任意の点の位置座標は次式で求められる。

(1) $\Delta Z<0$ かつ $\beta>\theta$ の場合 :

$$
\begin{aligned}
X_{0} & =d \\
Y_{0} & =L \cos \alpha \\
Z_{0} & =h+\mathrm{L} \sin \alpha \\
\mathrm{L} & =f d / k \Delta x \\
\alpha & =\beta-\theta
\end{aligned}
$$

(2) $\Delta \mathrm{Z}<0$ 加 $\beta \leqq \theta$ の場合 :

$$
\begin{aligned}
X_{0} & =d \\
Y_{0} & =L \cos \alpha \\
Z_{0} & =h-\mathrm{L} \sin \alpha \\
\mathrm{L} & =f d / k \Delta x \\
\alpha & =\beta-\theta
\end{aligned}
$$

（3） $\Delta \mathrm{Z} \geqq 0$ の場合 :

$X_{0}=d$

$Y_{0}=L \cos \alpha$ 

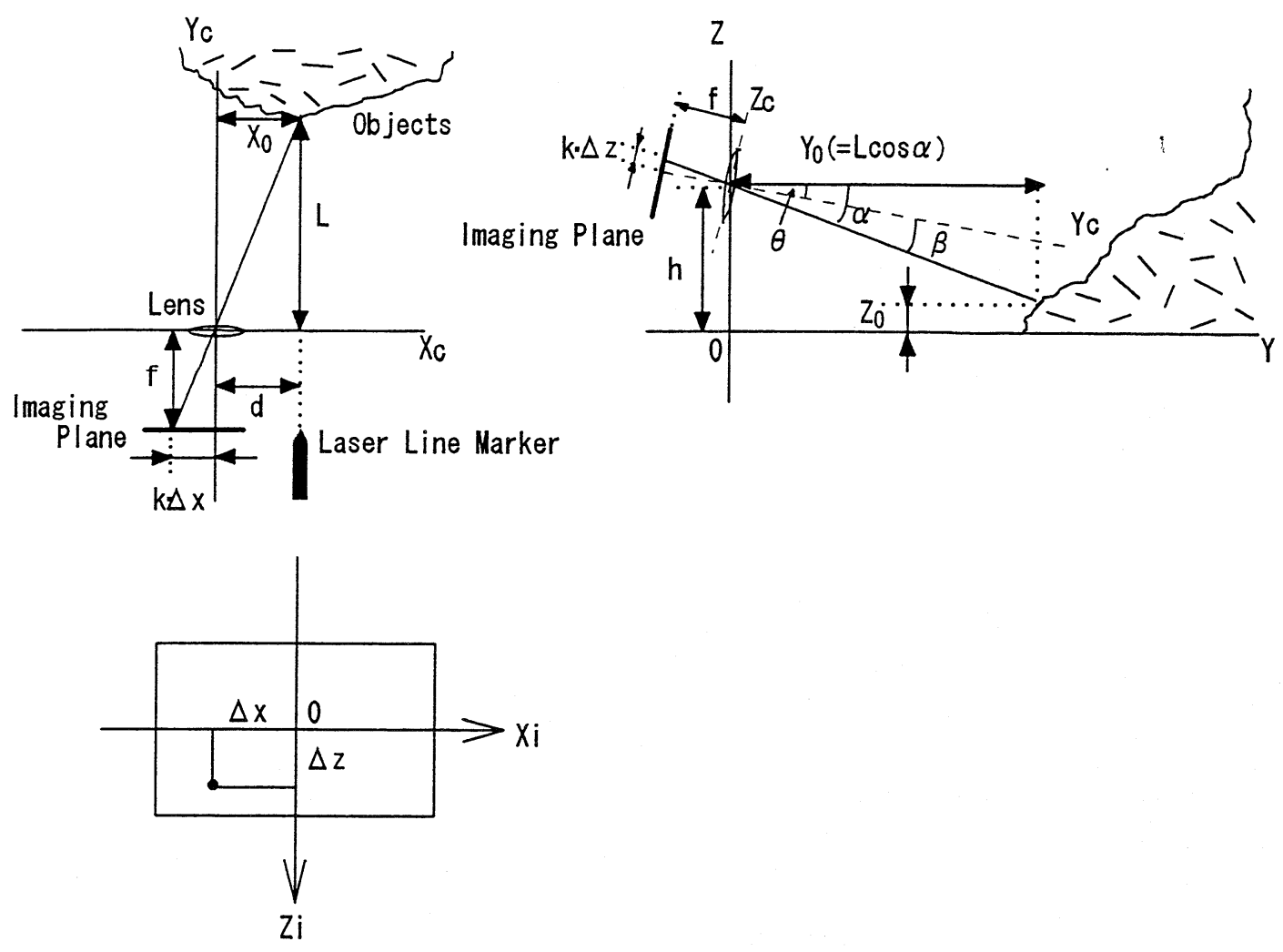

Fig. 1 Principle of distance measurement

$$
\begin{aligned}
Z_{0} & =h-\mathrm{L} \sin \alpha \\
\mathrm{L} & =f d / k \Delta x \\
\alpha & =\beta+\theta
\end{aligned}
$$

ただし, f はレンズの焦点距離, d はカメラとレーザー スリット光照射装置との間の距離, $\mathrm{k}$ は本光学系に固 有の定数, $\mathrm{h}$ はレンズの中心の高さ, $\theta$ はカメラの傾 斜角である。

上式を用いることにより，レーザー光が照射されて いるライン上の任意の点の位置座標が求められ，この 結果を $\mathrm{Y}-\mathrm{Z}$ 平面で表示すると Fig. 2のようになる。 Fig. 2 に示される計测結果中の，Y 方向および Z 方 向の最大值および最小值をそれぞれ $\mathrm{L}_{\max }, \mathrm{H}_{\max }, \mathrm{L}_{\min }$, $\mathrm{H}_{\min }$ とし, $\left(\mathrm{L}_{\max }-\mathrm{L}_{\text {min }}\right)$ および $\left(\mathrm{H}_{\max }-\mathrm{H}_{\min }\right)$ で囲ま れる長方形の面積 $\mathrm{S}_{\mathrm{ALL}}$ に対して, 画像より得られる 計測結果および $\mathrm{Y}$ 軸, $\mathrm{Z}$ 軸で囲まれた面積 $\mathrm{S}_{\text {ヶ }}$ との割 合を計算する。ずり山が存在すれば，この割合は大き くなるが,ずり山が存在しなければこの值は小さな值

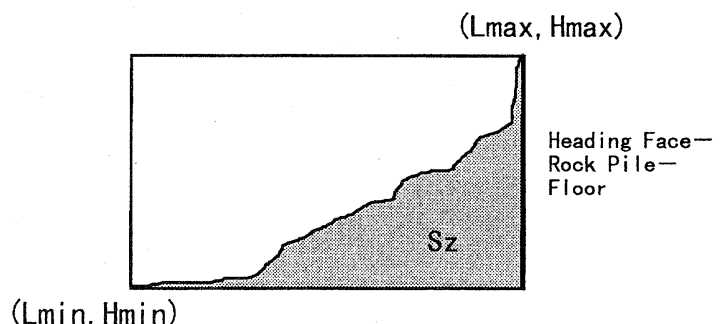

Fig. 2 Schematic diagram of measurements displayed in $\mathrm{Y}-\mathrm{Z}$ plane (Heading face-Rock pile-Floor)

となる。また計測結果にはある程度䛊差を含み，さら に壁面が多少傾斜している場合などでは，Fig. 3 に示 すようにずり山が存在しなくても面積比が大きくなる 可能性がある。従って, 次に $\left(\mathrm{L}_{\max }-\mathrm{L}_{\text {min }}\right)$ と $\left(\mathrm{H}_{\max }-\right.$ $\mathrm{H}_{\text {min }}$ ）の長さの比率 LH を計算する。地面だけを対象 


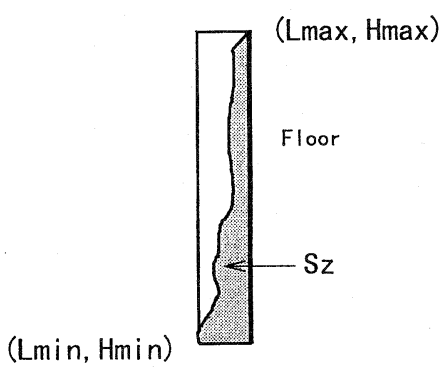

Fig. 3 Schematic diagram of measurements displayed in Y-Z plane (Heading face)

にした画像では, このLHの值は小さくなり，また壁 面だけを対象にした画像では，逆に LH の值が大きく なる。従って, ずり山が存在する画像では, この LH の値はある範囲内の値となることが予想される。それ ゆえ，上述の考察を基に，以下に示すような 2 つの条 件式を提案し，この 2 式を共に満足した場合，「ずり 山が存在する」と判断することにする。

$$
\begin{aligned}
& \text { - } \frac{S_{z}}{S_{A L L}} \geqq \varepsilon \\
& \text { - } a<\frac{\left(H_{\max }-H_{\text {min }}\right)}{\left(L_{\max }-L_{\text {min }}\right)}<b
\end{aligned}
$$

(4) および (5) 式中の $\varepsilon, a$ および $b$ は条件判断の ためのしきい值であり，これについては実験結果を基 に, 最適な認識結果が得られるような值を試行錯誤的 に決定する。

次に，“有”之判断された画像に対しては，(1)～(4) のパターンが考えられるため, (1)〜 (4)のパターンを認 識する。パターンの認識にはテンプレートマッチング 法を用いる。

テンプレートとしては, Fig. 4 に示すような単純な 形状のものを用いた。(1)および(2)「壁面一ずり山一 地面」に対するテンプレート，(3)および(4)は，「壁面一 ずり山」に対するテンプレート，(5)および(6)は,「ず り山一地面」に対するテンプレートであり，また(7)は 「ずり山」のみに対するテンプレートである。(7)以外

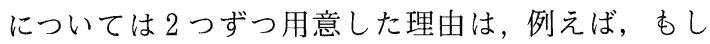
「壁面一ずり山」を撮影した画像において，壁面の部 分が僅かで，大部分がずり山であった場合，マッチン グの結果, (3)で示される「壁面一ずり山」よりも(7)の 「ずり山」のみのテンプレートの方が相関が良くなり, その結果, 認識結果を「ずり山」と出力する危険性が
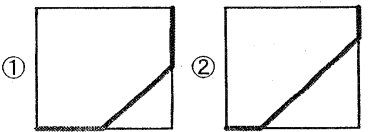
Heading Face-Rock Pile-Floor

(3)
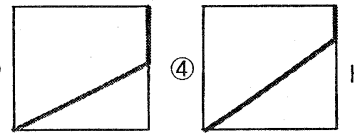

Heading Face-Rock Pile
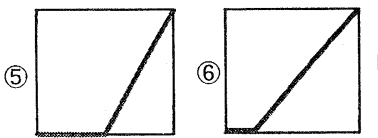

Rock Pile-Floor

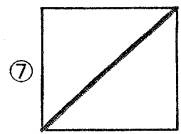

Rock Pile

Fig. 4 Templates used in this study

あり，その誤認識の可能性を少なくするために 2 種類 のテンプレートを用意した。

次に, Fig. 4 に示されるテンブレートと計測結果と をマッチングさせる訳であるが，同じずり山を対象に して撮影しても, 撮影の位置が变われば, 計測結果は 異なる。それゆえ，マッチングを容易にするため，テ ンプレートの大きさを $128 \times 128$ 画素で作成し，また 計測結果を比例配分を用いて $128 \times 128$ の大きさに変 形した。すなわち，縦および横の倍率は，それぞれ $128 /\left(H_{\max }-H_{\min }\right)$, および $128 /\left(L_{\max }-L_{\min }\right)$ であり, この倍率を用いてテンプレートと同じ大きさに合わせ た。このようにすると, いずれの計測結果もテンプレー トと同じ大きさになり，マッチングが容易になる。

パターンの認識では, 両者の間の距離の二乗を計算 し，最小のものをパターンの候補とする。すなわち以 下の式でテンプレートと計測結果との間の距離を求め, $r_{i}$ の值が最小となる時のテンプレートをパターン認識 の結果として出力する。

$$
\begin{aligned}
& r_{i}= \sum_{j=1}^{\mathrm{n}}\left(T_{j}-O_{j}\right)^{2} \\
& \mathrm{i}: \text { テンプレートの番号 } \\
& T_{j}: \text { テンプレートの特徴量 } \\
& \mathrm{O}_{\mathrm{j}} \text { : 実際の対象物の特徴量 }
\end{aligned}
$$

$\mathrm{T}_{\mathrm{j}}$ - $\mathrm{O}_{\mathrm{j}}$ は, 実際には以下のようにして求めた。Fig. 5 に示すように計測結果を $\mathrm{n}$ 点に離散化し, 計測点 $\mathrm{j}$ が領域 A にある場合は, $\mathrm{j}$ 点から鉛直線を引き，地面 に相当する水平軸までの距離を $\mathrm{T}_{\mathrm{j}}-\mathrm{O}_{\mathrm{j}}$ とし, $\mathrm{j}$ 点が 


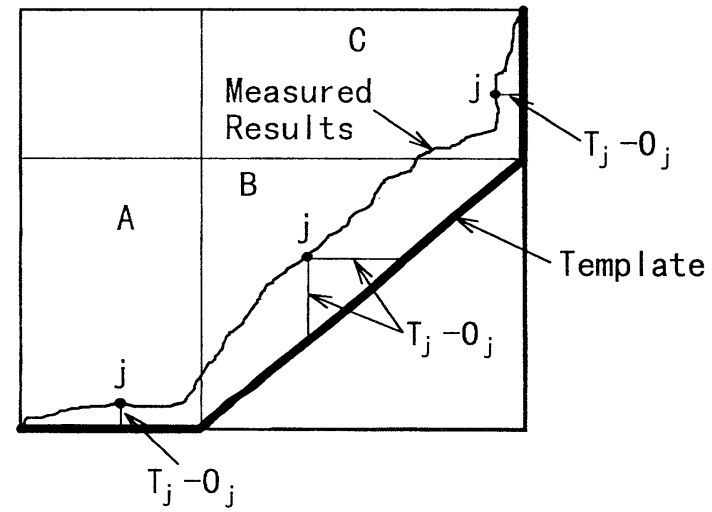

Fig. 5 Schematic diagram for matching between measured results and templates

領域 B にある場合は, $\mathrm{j}$ 点から水平方向抢よび鉛直方 向に線をのばし，それぞれがテンプレートの線分に到 達するまでの距離の和を $\mathrm{T}_{\mathrm{j}}-\mathrm{O}_{\mathrm{j}}$ とし，また $\mathrm{j}$ 点が領 域 Cにある場合は, $\mathrm{j}$ 点から水平線を引き，壁面に相 当する鉛直軸までの距離を $\mathrm{T}_{\mathrm{j}}-\mathrm{O}_{\mathrm{j}}$ とした。

一方，“無”と判断された画像に対しては，比率 LH の值を用いれば, (5)〜 (7)のパターンの認識は容易に行 われる。

\section{3. 実験装置および画像の一例}

本実験で用いた装置の概略をFig. 6 に示した。CCD カメラは水平方より $10^{\circ}$ 傾斜させて設置し，レンズ中 心の高さは, $\mathrm{h}=188 \mathrm{~mm}$ である。またレーザースリッ 卜光照射装置はカメラと $100 \mathrm{~mm}$ 離して設置してある。 カメラはSONY 社製 CCD - MCI を用いた。レンズの 焦点距離はf $\mathrm{f}=6.207 \mathrm{~mm}$ である。実験に用いた画像

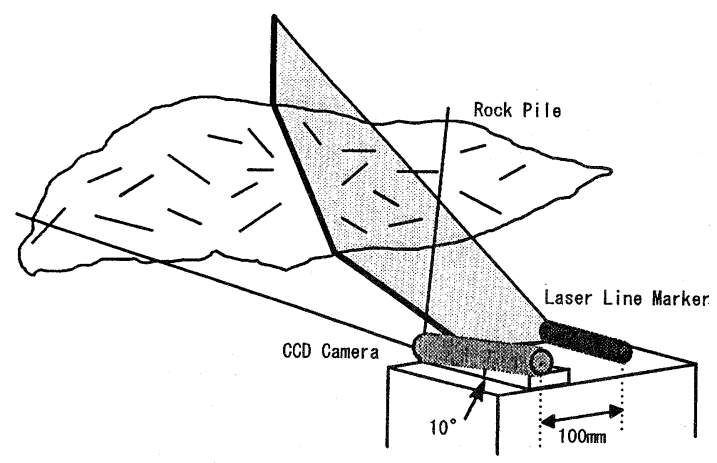

Fig. 6 Outline of experimental apparatus
処理装置は PIAS 社製の LA - 525 であり, パーソナル コンピュータと接続され, 種々の処理が連続的にでき るようになっている。本画像処理装置では, アナログ 画像は $512 \times 512$ 画素に標本化され，それぞれの画素 に対して 256 階調に量子化され，ディジタル画像に変 換される。

Fig. 7 に, 撮影された画像の 2 值画像および細線化 処理を施した画像の一例を示した。Fig. 7 (1)〜 (3) は，それぞれ「壁面一ずり山一地面」「壁面一ずり山」

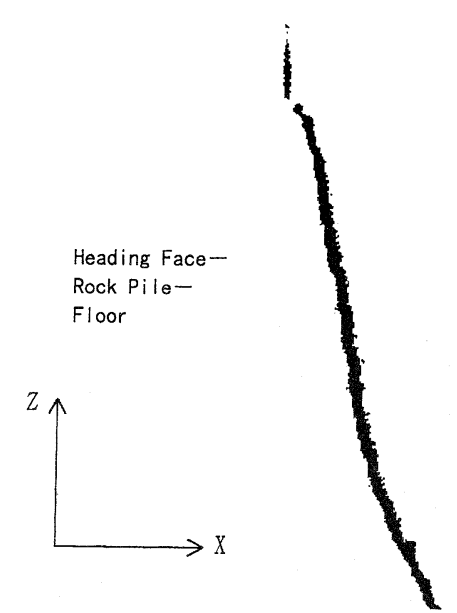

(a)

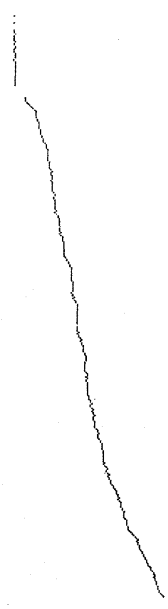

(b)
Fig. 7 (1) An example of original and thinned image (Heading face-Rock pile-Floor)

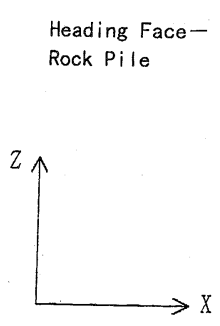

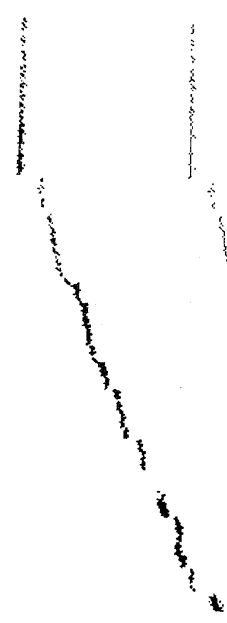

(a)



(b)
Fig. 7 (2) An example of original and thinned image (Heading face-Rock pile) 

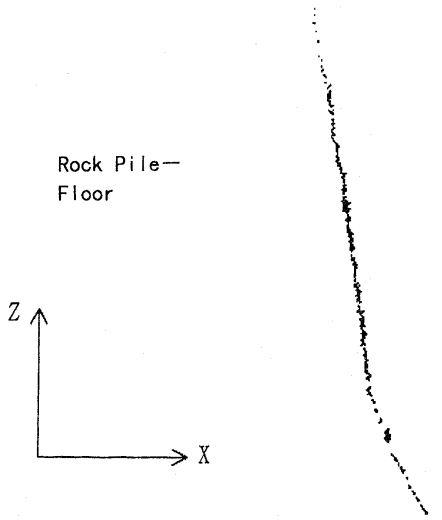

(a)

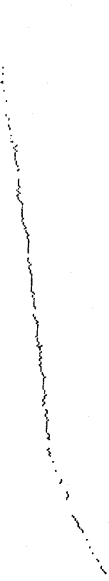

(b)

Fig. 7 (3) An example of original and thinned image (Rock pile-Floor)

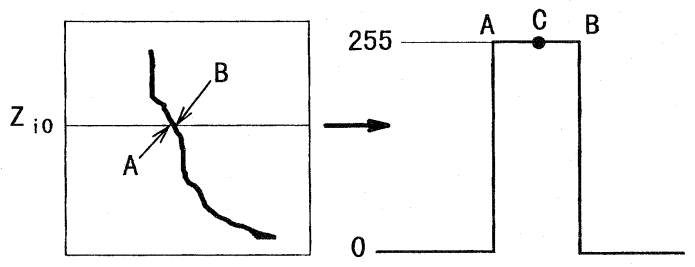

Fig. 8 Explanation of detecting center point

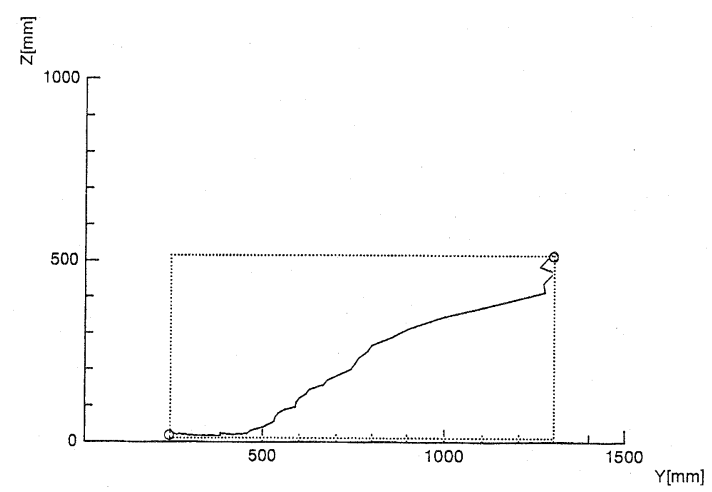

Fig. 9 (1) Measured results (Heading face-Rock pile-Floor)

および「ずり山一地面」を撮影したものである。（a） は 2 值画像を，また（b）は細線化処理を施した後の 結果を示している。必要な情報はレーザースリット光 の画像のみであるため, 光源を点灯しないで撮影を行っ

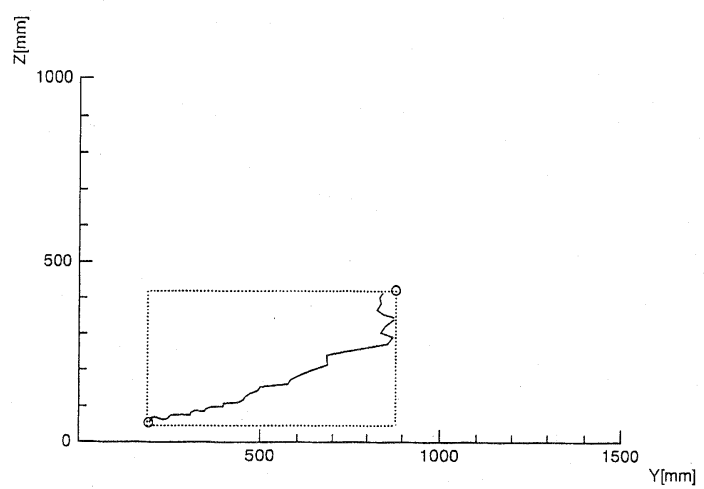

Fig. 9 (2) Measured results (Heading face-Rock pile)

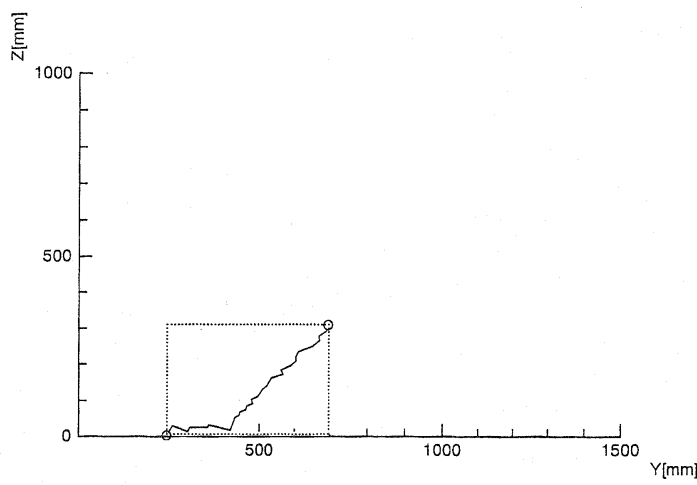

Fig. 9 (3) Measured results (Rock pile-Floor)

ている。そのため, 図に示されるようにレーザーのラ インのみが写っている。

細線化処理は以下のようにして行った。初めに，撮 影された原画像に対して画像強度值のしきい值を 30 として 2 值化処理を行う。その結果, レーザー光の部 分はFig. 7 に示すようにある幅を持って検出される ので, 例えば, Fig. 8 に示すように $Z_{\mathrm{i}}=Z_{\mathrm{i} 0}$ の横 1 ラ インにおいて画像強度值が 0 から 255 に変化する点 $\mathrm{A}$ および 255 から 0 に変化する点 $\mathrm{B}$ の 2 点を求め, その 中点 $\mathrm{C}$ を検出する。これを全ての $\mathrm{Z}_{\mathrm{i}}$ に対して行い，C 点のみをプロットすればFig. 7（b）に示されるよう な結果が得られる。なお，しきい值 30 は，レーザー光 の反射の影響等を考慮し, 試行錯誤により決定した。 また Fig. 9 は，Fig.7のそれぞれについて，(1) 式 より求められる距離計測結果を Y-Z 平面で表したも のである。 


\section{4. 結果および考察}

本研究で提案するアルゴリズムの有効性を確かめる ために実験を行った結果をTable 1 に示した。Table 1 には撮影された 31 画像に対して有無判断およびパ ターン認識を行った際の成功率を示したが, 本研究で 提案したずり山存在の条件式による有無判断において は，100\%の成功率を示した。なお，この際に用いた （4）および（5）式中のしきい值は, 画像の解析結果 を基に, パターン認識の結果が最も良好になる值をそ れぞれ試行錯誤的に決定し，それぞれ $\varepsilon=0.2, a=$ 0.2 および $\mathrm{b}=3.0$ の值が得られた。Table 1 にはパ ターン認識の結果も併せ示した。ここに示されるよう に, パターン認識の成功率は約 80\%であった。ここで の誤判断は全てずり山存在画像に対して生じたが，こ れは，ずり山などの本来不定形である対象物に対して， 直線で近似した単純なテンプレートを用いたことに起 因していると考えられる。これに対処する方法の 1 つ として, より複雑なテンプレートを用意することが挙 げられるが，不定形のあのを対象にするには，極端に 言えば無数のテンプレートを用意しなければならず，

Table 1 Recognition results

\begin{tabular}{|c|c|c|}
\hline $\begin{array}{c}\text { Judgment for the } \\
\text { Existence of the } \\
\text { Rock Pile }\end{array}$ & $\begin{array}{c}\text { Pattern Recognition by } \\
\text { Use of the Minimum } \\
\text { Distance }\end{array}$ & $\begin{array}{c}\text { Pattern Recognition by } \\
\text { Use of the Algor ithm } \\
\text { Proposed in This Study }\end{array}$ \\
\hline $100 \%$ & $80.6 \%$ & $100 \%$ \\
\hline
\end{tabular}
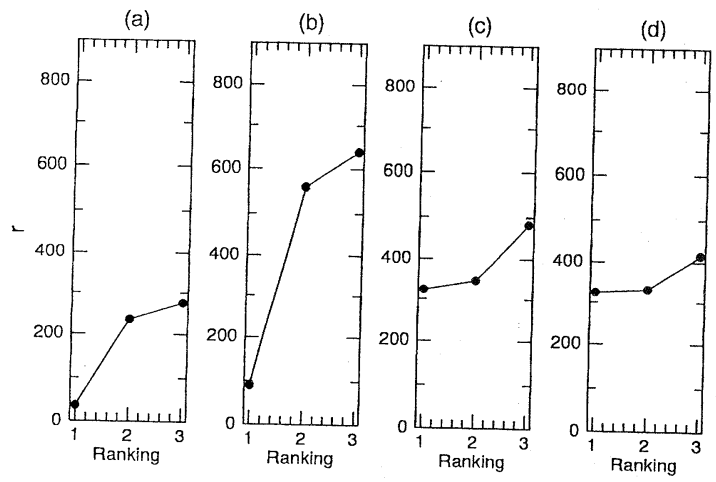

Fig. 10 Examples of calculated results for distance between templates and measured results
これでは現実味に欠ける。そこで，本研究では以下の ようなアルゴリズムを提案する。

Fig.10にマッチングの結果の一例を示した。縦軸 は（6）式より計算されるテンプレートと計測結果と の間の距離を示し，横軸は候補の順位を示している。 すなわち, 1 はr の值が最小になったテンプレートを， 2 および 3 は $\mathrm{r}$ の值が 2 番目および 3 番目に小さいテ ンプレートを示す。Fig.10の（a）および（b）は認 識が正しく行われた時の結果であり，(c) および (d) は認識が正しく行われなかった時の結果である。これ を見ると，第 1 候補の $\mathrm{r}$ の值そのものが小さく，かつ 第 2 および第 3 候補の $\mathrm{r}$ の值之の差が大きい場合は認 識が正しく行われるが, 第 1 候補の值が第 2 および第 3 候補の $\mathrm{r}$ の值と比べて，あまり差が大きくないよう な場合には, 認識が正しく行われない確率が高いこと が分かる。それゆえ, 本研究では, 次のようなアルゴ リズムを提案する。すなわち（6）式から計算される $r_{i}$ の值および（7）式に示す関係式を用いて，最終的 にパターンを判断するようにする。

$$
\mathrm{r}_{1} / 2<\left(\mathrm{r}_{2}-\mathrm{r}_{1}\right)
$$

上式を満足するあのは，認識の結果として “第 1 候補” を出力し，それ以外は “第 1 , 第 2 あるいは第 3 候補 のいずれかである”と出力する。

新たなアルゴリズムを用いたパターン認識の結果は, Table 1に示したように100\%となった。ただし， “第 1 , 第 2 あるいは第 3 候補のいずれかである” と

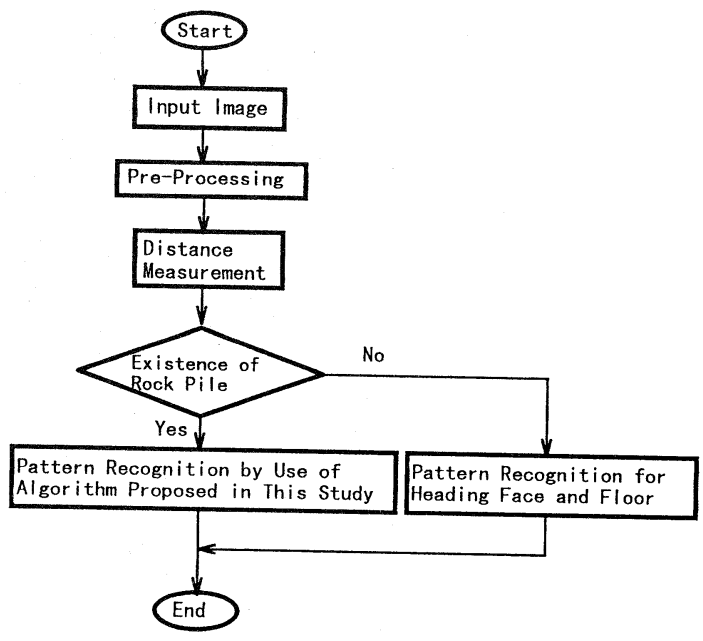

Fig. 11 Frow chart of procedure 
出力された結果は, 31 画像中 6 枚あり,この場合は実 際の画像が第 4 候補でなく, 第 1 , 第 2 あるいは第 3 候 補であれば, 誤判断ではないとして成功例にカウント した結果であり, 従って, 全てのパターンが一意に認 識されたということではない。“第 1 , 第 2 あるいは第 3 候補のいずれかである”と判断された場合には，機 械自身が前進あるいは後退して新たに画像を撮影し， （7）式を満足するような状態が得られるまで同様な操 作を繰り返せば，確実なパターン認識が行われると考 えられる。

なお，本アルゴリズムを用いて，撮影された画像か ら認識結果を出力するまでの処理時間は約 1 秒であり， ほぼリアルタイム処理が可能であることが確認された。 また, 全体の処理の流れをFig. 11 に示した。

\section{5. むすび}

本研究では, 知能開発機械ロボット実現への基礎的 研究として, 画像とレーザースリット光を用いた破砕 堆積物認識のためのビジョンシステムの構築を試みた。 本研究で提案したアルゴリズムを用いると,ずり山存 在の有無は $100 \%$ ，また堆積の状態もほぼ認識される ことが分かり，本システムの有効性が確かめられたも のと考える。なお，本アルゴリズムによっておパター ンを一意に特定し得ない場合は，撮影した位置から前 進あるいは後退して撮影し直すことなどが必要になる と考えるが，これらは今後の課題であり，さらにこの
視覚情報の他に, 実際に対象物にバケットか何かで触 れてみるといった力覚情報などを統合させ, より詳細 な環境認識を試みる予定である。

\section{主な記号}

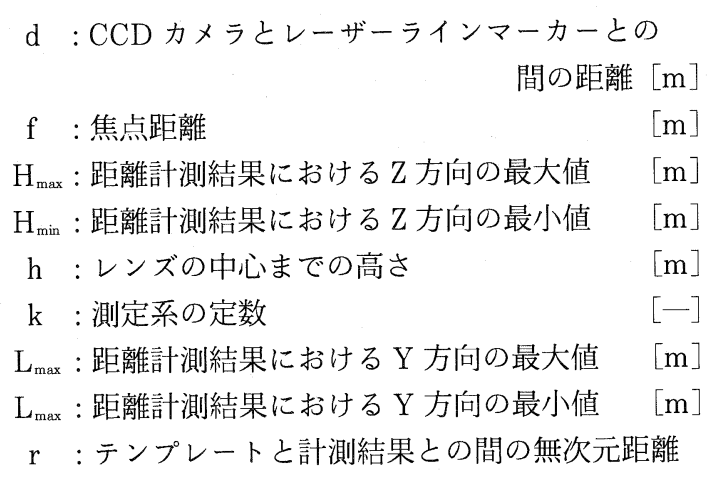

$\alpha$ : 角度 (Fig. 1 参照)

[deg.]

$\beta$ : 角度 (Fig. 1参照)

[deg. $]$

$\theta$ : カメラの水平軸に対する傾斜角

[deg.]

\section{参考文献}

1）西松 裕一, 平成 3 年度資源素材関係学協会合同 秋季大会分科研究会資料, pp. 29-32（1991）

2）鎌田博之, 東北大学修士学位論文 (1995)

3）舟久保登, 視覚パターンの処理と認識, pp. 303308 (1990) 啓学出版. 